\title{
The Role Self-Regulated Learning on Project-Based Learning to Natural Science Learning Outcome
}

\author{
Sudiyono* \\ Department of Post-Graduate \\ Kanjuruhan University of Malang \\ Malang, Indonesia \\ *sudiyono@unikama.ac.id
}

\author{
Maris Kurniawati, Danang Aditya Nugraha \\ Department of Science and Technology \\ Kanjuruhan University of Malang \\ Malang, Indonesia \\ maris@unikama.ac.id, danang.adty@unikama.ac.id
}

\begin{abstract}
Many factors influence the acquisition of learning outcomes, both external and internal factors. One internal factor that is thought to be very influential on the achievement of learning outcomes is Self-Regulated Learning (SRL), while external factors that are thought to contribute to the achievement of learning outcomes are the learning strategies teachers use this case, Project-Based Learning (PjBL). This research aims to assess the effect of PjBL and SRL on natural science learning outcomes. The subjects were 153 students from the Elementary Teacher Education of the Kanjuruhan University of Malang. The research design used a $2 \times 2$ factorial quasi-experiment. The instruments of data collection were questionnaires and tests. Validation of instruments using: (1) validity test of "expert judgment" content, (2) construct validity test using exploratory factor analysis, (3) reliability test using Cronbach Alpha with the result value is $0.941(>0.600)$. The data were analyzed using twoway ANOVA with $\alpha=0.05$. Findings: (1) There is a difference in science learning result between students who were studied using PjBL with students who were studied using regular strategy; (2) There is a difference of science learning result between the student with high and low SRL ability; 3) There is an interaction between PjBL and SRL on natural science learning outcomes. This study result is useful for improving the quality of the learning process by actively involving students. The activeness of students in learning both physically and mentally or emotionally is very important for learning participants' interests.
\end{abstract}

Keywords-SRL, PjBL, natural science, learning outcome

\section{INTRODUCTION}

The achievement of high learning outcomes in students is always a target of every learning process. The learning outcomes, according to Reigeluth [1], consist of three dimensions: (1) The effectiveness of learning, (2) Efficiency, and (3) Learning attractiveness. Learning effectiveness is the acquisition associated with the learning objectives. Indicators of learning effectiveness include (i) accuracy of behavioral mastery, (ii) performance velocity, (iii) compliance with procedures, (iv) quality of performance, (v) quality of result, (vi) rate of transfer of learning, and (vii) retention rate. Learning efficiency refers to how much time, energy, and learning resources are used in learning. The attractiveness of learning is the interest and sincerity of students to desire to learn more. Teachers make various efforts to improve student learning outcomes, among others, by the implementation of learning methods that are considered by the objectives. Many factors influence the acquisition of learning outcomes, both external and internal factors. "SRL is a process that students use to focus their thoughts, feelings, and actions systematically to achieve goals" [2]. How the role of SRL in the learning process has been revealed by many experts and researchers, as summarized by Zumbrunn et al. [3]. SRL also helps students to create good learning habits and therefore could strengthen their skills in a study Wolters [4], enhance learning outcomes by applying new learning strategies [5] and lastly to evaluate their academic progress [6]. Furthermore, in SRL, motivation could be an important factor in students' academic outcomes [7].

$\mathrm{PjBL}$ has characteristics that allowed learners to be active, creative, productive, and collaborative. Through the constructive learning process, the learners can do learning activities using cognitive, affective, and psychomotor abilities and achieve optimal learning outcomes. Thus, PjBL is possible to support the acquisition of learning outcomes significantly. "In PjBL, the project is part of the teaching and learning strategy. Students explore and learn the concept and application through the project." [8].

"The students who were taught using PjBL strategy performed significantly better in terms of self-directed learning skills than did students who were taught using CT strategy" [9]. "PjBL was more effective in the positive development of the student's academic achievement levels. The students who were educated by project-based learning were more successful and had higher attitude levels towards the lesson than the students who were educated by the instruction based on student textbooks" [10]. "The most valuable from PjBL approach was to observe the production of new knowledge derived from students' own investigation and exploration" [11]. The integration between the use of PjBL method and SRL ability will be able to improve student learning outcomes. This is based on the $\mathrm{PjBL}$ characteristics that need independence and active involvement from learners in physically, mentally, and emotionally into their learning process. 
This study aimed to determine the effect of SRL on the use of the PjBL method for learning elementary school science. The study design was a quasi $2 \times 2$ experiment with 153 prospective teacher students (four learning classes), two classes as a treatment group and 2 classes as a control group. The intake group does the placement of research subjects in the learning group. A different lecturer teaches each group. The research data collection instrument used was a test, questionnaire, and observation sheet. Research data were analyzed using a t-test and one-way ANOVA.

\section{A. The Role of SRL to Learning Outcome}

"Self-regulation is a personality capacity that includes selfdirected motivation" [12]. Self-regulation plays a role in selfdirected learners to have independence in learning. A good self-regulated learner has a combination of academic learning skills and self-control that makes learning easier for them and makes them more motivated. "Students who have high ability in managing their learning can transform their mental abilities into academic skills and strategies" [13]. Many factors can influence the acquisition of a person's learning outcomes, both external and internal. One of the interesting and actual internal factors to examine is the ability of self-regulation. There is a clear goal in formal education namely: to improve and update skills, seek new knowledge, and solve existing problems in life. This is a significant factor for students to develop their abilities and be self-regulated as it has been proven to give a specific picture of the various components that affect success. Selfregulation is learning that occurs on the initiative. "Students who have the initiative demonstrate the ability to use their thoughts, feelings, strategies and behaviours that are shown to achieve goals" [7]. SRL deals with one's habit of discipline, self-control, and initiative in learning. Students whose initiative is high in learning activities will reveal active, creative, and dynamic behaviours in learning, thereby increasing their learning outcomes.

According to Friedman and Schustack "Self-regulation is the process of a person in managing the action and obtaining his own learning outcomes, determining the targets to be achieved, measuring his success, and rewarding himself for the results achieved" [14]. Pintrich, define "self-regulation as an active and constructive process, where students set their own learning goals, monitor, regulate their implementation, try to control their thoughts, enthusiasm, and behavior, guided and limited by the goals to be achieved and the context of their environment" [15]. Zimmerman views self-regulation refers to the "Process used by students to focus their thoughts, feelings, and actions systematically on achieving goals" [2]. Selfregulation requires students to have choices, for example, related to what will be done and how they will do it. "Selfregulation in learning can be seen as a mechanism to help explain differences in abilities among students and is a meaningful matter for the development of abilities" [16].

SRL also implies that a person can also avoid interference from his environment and emotional aspects that can interfere with his development. People regulate their behavior by setting personal goals and evaluating their behavior according to performance evaluation standards [12]. Bandura in Schunk mentions three stages in self-regulation [16]: (1) Selfobservation, how a person sees himself and his behaviour and continues to watch over him. (2) Assessment, as a process of comparing what is seen in themselves and their behavior with a certain standard size. (3) Self-response, the stage of giving a response to yourself in return for the assessment that has been done. Forms of self-response can range from very obvious, such as working hard or studying until late at night to implicit ones such as feelings of pride or shame. Zimmerman developed a self-regulation cycle model consisting of three stages: thinking, performance, and self-reflection [2]. At the stage of thinking organization, students plan and set their strategies to achieve goals. For example, students can make plans to complete a chapter or book. Students independently demonstrate the ability to control themselves through independent learning, focusing attention, and managing strategies in completing assignments in the performance phase. Students in this phase use background knowledge and selective strategies to understand and comprehend texts during a reading. This can also include working with others and having conversations to understand the text better. Finally, the selfreflection phase, students bring themselves back to evaluate and understand their performance. Did they complete what they planned to achieve, and what the next steps were [17]?

Research on self-regulation in learning begins with developing psychological studies into the development of selfcontrol by adults and children. Much of the research on selfregulation used to be carried out in a clinical context, where researchers taught participants to change dysfunction behaviors such as aggression, addiction, sexual deviations, personal conflicts, and behavior problems at home and school. Finally, at this time self-regulation has been developed to discuss learning and academic achievement [16]. Self-regulation involves someone's behaviour when someone regulates their behaviour to focus on achieving goals. Self-regulation also involves cognitive variables and other influential variables. In learning, self-regulation is beneficial for students to maintain their self-confidence in learning by believing that positive results will arise and maintain a positive emotional state (for example, feeling proud of the results achieved). Associated with process and self-regulation strategies applied by students have a variety in general (applied to various types of learning), and specifically (applied only to certain types of learning).

Conditioning by self-monitoring and external monitoring gives rise to higher self-efficacy, ability, and tenacity than conditioning without monitoring. The benefits of monitoring do not depend on the child's performance during the learning process. Monitoring progress, rather than evaluating it, will improve children's perceptions of their learning progress and self-confidence. Self-monitoring and, in combination with implementation, is often a key component of in effective interventions. 


\section{Some research result about SRL}

- Self-monitoring of the belief in achieving goals will maintain learning and increase achievement $[2,18,19]$.

- Effective self-regulation develops self-efficacy for learning settings. Attitudes towards learning and strategies in dealing with tests have a strong influence on learning outcomes in mathematics.

- Students' SRL strategies influence 3.Scholastic performance of e-learning students more than other learning management systems [20].

- Through SRL in learning, teachers can provide students with information and opportunities and help them become strategic, motivated, and independent students.

- Pintrich believes that self-regulation activities bridge students' relationship and their environment and influence their performance [16].

- Student achievement at school shows that the triadic model of self-regulation has benefits in training students to become more effective learners

\section{B. The Role of PjBL to Learning Outcome}

Based on the concepts and findings of research results on PjBL and SRL, which both positively influence the acquisition of learning outcomes, the interaction of these two variables in learning can improve the learning outcomes. PjBL and SRL are conditions that can be built or developed within individuals through systematic education and learning efforts. Thus, the implementation of the PjBL strategy, accompanied by the efforts to optimize the learning ability to learn in learning, will have a positive effect on learners' learning achievement. In line with the concept and the findings of research findings on PjBL and SRL, which both positively influence the acquisition of learning outcomes, the interaction of the two variables in learning can increase learning outcomes. PjBL and SRL are conditions that can be built or developed within individuals through systematic education and learning efforts. The implementation of PjBL strategy which is accompanied by efforts to optimize the high SRL ability of students, will positively influence the acquisition of student learning outcomes.

According to the social cognitive theory of Bandura, people want to control events that affect their lives and see themselves as perpetrators. In the conception of consciousness as the agent of the most important thing, the self-regulation or process in the individual activates and maintains behavior, cognition, and influence, systematically oriented toward attaining goals [19]. Self-regulation requires students to have choices, for example related to what to do and how they will do it. Self-regulation in learning, can be seen as a mechanism to help explain differences in students' abilities and is a meaningful thing for the development of their abilities [16].
PjBL is a model of learning organization in the form of project activities. The project in question is complex tasks based on challenging questions or problems involving students in design, problem-solving, decision making, or in research activities. PjBL is a systematic learning strategy that involves students in learning knowledge and skills through complex inquiry processes, authentic questions, work design, and product acquisition [21]. PjBL provides students opportunities to work more independently for a long time and end up with a real product or a presentation. Through PjBL students occupy themselves with a variety of skills to open the way for metacognitive development that can last a long time. Characteristics of PJBL are: (1) Enriching and developing the ability to learn to form new knowledge. (2) Gaining the opportunity to actively participate in the learning process, conduct in-depth studies, and produce something. (3) Following the learning according to different bits of intelligence. (4) Provide opportunities for students to use their learning methods such as learning by reading, studying independently, or discussing with groups. (5) Seeing ways of learning that are different from others. This allows them to learn through the application. (6) Provide meaningful information to parents of students about changes in their learning performance.

$\mathrm{PjBL}$ is implemented by organizing students in a team to solve problems while producing a product. Important concepts in team learning methods are team appreciation, individual responsibility, and the same chance of success. Responsibility is focused on team members' activities in helping one another learn and ensure that each is ready to do their work.

Project-based learning strategies contribute to the development of the following skills and traits: 1) Learning skills with groups. 2) Cognitive process skills (decision making, critical thinking, and problem-solving skills). 3) Selfgovernance (planning activities, setting goals, and completing tasks). 4) Skills in managing attitude (motivation and desire to practice). 5) Self-tendency (self-directed, desire to excel). 6) Confidence (independence).

PjBL has the following characteristics: (1) A creative process for obtaining problem-solving solutions based on a specific need or problem. (2) A varying stage of natural development is needed to design solutions, for example, the accuracy of problem definition, solution requirements, and constraints; generation of alternative solutions and their evaluation by criteria; building model. (3) Requests for various skills related to different functions, such as information retrieval and retrieval; represent ideas using formal notation; build physical models. (4) Requests for collaborative work skills, for example, distribution of functions according to expertise; parallel and cooperative work. (5) There is a continuous evaluation of the product produced at each stage and the solution obtained. 


\section{METHODS}

This study's subjects were prospective elementary school teacher candidates from Kanjuruhan University Malang who were taking elementary science courses totaling 153 people who were selected by purposive sampling technique. The research subjects were divided into four classes, namely classes A, B, C, and D. Furthermore, the four classes were drawn using lottery paper rolls to determine which classes were the experimental and control groups. The drawing process was carried out jointly with the two lecturers who taught natural science learning subjects in the odd semester of the 2015-2016 academic year. From the draw, the results of class A (44 students) and class C (40 students) were selected as the experimental group, while class B (40 students) and class D (39 students) were selected as the control group. Determination of the number of classes and students in each class as lecture participants is determined by the academic administration department based on students' order in re-registering and the course programming process at the beginning of the semester without any other subjective considerations.

There are three variables of this research: (a) one independent variable (learning strategy) consisting of two dimensions, namely PJBL and regular learning strategy; (B) one moderator variable that has two dimensions of SRL that is, high SRL capability and low SRL capability; (C) one dependent variable that is, the result of natural science learning of the student. In accordance with the research design concept of Gall et al. [22], this study was designed using a quasiexperimental design of $2 \times 2$ factorial. Research subjects, both experimental and control groups, were not randomly selected but using subjects grouped into in the course class as it is. The data collection instrument used is the learning result test and the SRL capability measurement questionnaire. Test the validity of the instrument with content validity test, and construct validity. The learning result test is validated by content validity test through "expert judgment," while the SRL measurement questionnaire is validated by content validity test and construct validity using exploratory factor analysis. The result data were analyzed by (1) free sample t test, and (2) Analysis of two-way variant. In addition, descriptive analysis is also conducted to obtain a description of the students' initial knowledge.

\section{RESUltS AND DisCUSSION}

\section{A. Student Initial Knowledge}

Statistical data that illustrates the initial knowledge of students before the treatment can be seen from the results of the descriptive test and t-test, whose results are presented in Tables 1 and 2 below:
TABLE I. DESCRIPTION OF STUDENT INITIAL KNOWLEDGE

\begin{tabular}{|l|l|l|l|l|l|}
\hline \multicolumn{7}{|c|}{ Group Statistics } \\
\hline & \multicolumn{1}{|c|}{ Group } & \multicolumn{1}{|c|}{$\mathbf{N}$} & \multicolumn{1}{c|}{ Mean } & $\begin{array}{c}\text { Std. } \\
\text { Deviation }\end{array}$ & $\begin{array}{c}\text { Std. Error } \\
\text { Mean }\end{array}$ \\
\hline Initial & Experiment & 84 & 68,7619 & 3,27686 &, 35753 \\
\cline { 2 - 7 } Knowledge & Control & 69 & 68,7246 & 2,87425 &, 34602 \\
\hline
\end{tabular}

Table 1 shows that the results of learning science in the two groups of students in the experimental and control groups are relatively the same. The mean values were 68.76 and 68.72 , respectively. This shows that the initial abilities of students before treatment are the same.

Testing of differences in the initial ability of students in the experimental group and the control group before treatment using the test results in table 2 .

TABLE II. T-TEST RESULTS OF INITIAL KNOWLEDGE

\begin{tabular}{|l|c|c|c|c|c|c|}
\hline & F & Sig. & t & df & $\begin{array}{c}\text { Sig. (2- } \\
\text { tailed) }\end{array}$ & $\begin{array}{c}\text { Mean } \\
\text { Difference }\end{array}$ \\
\hline $\begin{array}{l}\text { Equal } \\
\text { variances } \\
\text { assumed } \\
\begin{array}{l}\text { Equal } \\
\text { variances not } \\
\text { assumed }\end{array}\end{array}$ &, 497 &, 482 &, 074 & 151 &, 941 &, 03727 \\
\hline
\end{tabular}

A requirement before analysis of the results of the free sample t-test is to test the variants' similarity. The variance similarity test results with Levene's test obtained F count with Equal variance assumed was 0.497 with a probability of 0.482 . The probability value is $>0.05$, meaning $\mathrm{H} 0$ is accepted, or it can be stated that the two variances are not different. Based on the results of the similarity test of the variance, the analysis of the results of the t-test was continued by using the Equal variance assumed basis (assumed both variances are the same). The free sample t-test presented in Table 2 obtained t values of 0.074 with a probability of 0.941 . In a two-sided test, the probability is $0.941 / 2=0.470(>0.025)$ means that there is no difference in initial knowledge between the experimental group students and the control group. This can be interpreted that the mastery of elementary science by the two groups of students before treatment did not significantly differ.

\section{B. Description of Student Learning Outcomes After Treatment}

Descriptive data of student learning outcomes obtained after treatment (post-test) is presented in table 3. 
TABLE III. DESCRIPTIVE DATA OF STUDENT LEARNING OUTCOMES

\begin{tabular}{|l|l|l|l|l|}
\hline \multicolumn{5}{|c|}{ Dependent Variable: Learning Outcomes } \\
\hline \multirow{2}{*}{ Groups } & \multicolumn{1}{|c|}{ SRL } & Mean & $\begin{array}{c}\text { Std. } \\
\text { Deviation }\end{array}$ & $\boldsymbol{N}$ \\
\hline \multirow{5}{*}{ Experiment } & High & 82,3175 & 3,80503 & 63 \\
\cline { 2 - 6 } & Low & 75,5714 & 10,39024 & 21 \\
\cline { 2 - 6 } & Total & 80,6310 & 6,74274 & 84 \\
\hline \multirow{5}{*}{ Control } & High & 71,9130 & 2,15139 & 23 \\
\cline { 2 - 6 } & Low & 70,3043 & 1,45861 & 46 \\
\cline { 2 - 6 } & Total & 70,8406 & 1,86786 & 69 \\
\hline \multirow{5}{*}{ Total } & High & 79,5349 & 5,76337 & 86 \\
\cline { 2 - 6 } & Low & 71,9552 & 6,34234 & 67 \\
\cline { 2 - 6 } & Total & 76,2157 & 7,09052 & 153 \\
\hline
\end{tabular}

Table 3 shows that when viewed from the SRL ability in the two categories, the experimental group's mean learning outcomes were higher than those of the control group. In the high SRL category, the mean value of learning outcomes achieved by the experimental group was 82.31, while the control group was 71.91. In the low SRL category, the mean value of the experimental group learning outcomes was 75.57, and the control group was 70.30. The interesting thing is that the mean score of learning outcomes in the experimental group with low SRL is 75.57, which is higher than that of the control group with a high SRL of 71.91. This can explain that the learning strategy applied to the experimental group provides higher learning outcomes than the conventional learning strategy applied to the control group.

TABLE IV. TwO WAY ANOVA TEST RESUlt

\begin{tabular}{|c|c|c|c|c|c|}
\hline \multicolumn{6}{|c|}{ Dependent Variable: Learning outcome } \\
\hline Source & \begin{tabular}{|c} 
Type III Sum \\
of Squares
\end{tabular} & Df & Mean Square & $\mathbf{F}$ & Sig. \\
\hline Corrected Model & $4387,523^{\mathrm{a}}$ & 3 & 1462,508 & 66,961 & 000 \\
\hline Intercept & 699744,860 & 1 & 699744,860 & 32037,6 & 000 \\
\hline X1 (Learning Strategy) & 1908,141 & 1 & 1908,141 & 42 &, 000 \\
\hline X2 (SR Ability) & 542,318 & 1 & 542,318 & 87,364 & 000 \\
\hline $\mathrm{X} 1 * \mathrm{X} 2$ & 205,053 & 1 & 205,053 & 24,830 &, 003 \\
\hline Error & 3254,359 & 149 & 21,841 & 9,388 & \\
\hline Total & 896393,000 & 153 & & & \\
\hline Corrected Total & 7641,882 & 152 & & & \\
\hline
\end{tabular}

Two-way ANOVA test results, whose data are presented in Table 6 regarding the interaction between the PjBL strategy and self-regulation on learning outcomes, obtained the coefficient $\mathrm{F}$ is 9.388 and the significance of 0.003 . Significance of $0.003(<0.05)$ means that $\mathrm{HO}$ is rejected, or it can be stated that there is a significant interaction effect of using the PjBL strategy with the ability to self-regulate learning outcomes. It can be interpreted that the use of $\mathrm{PjBL}$ strategies in students with high self-regulation abilities will provide high learning outcomes. Students' self-regulation ability will strengthen the connectivity of the use of PBP strategies with learning outcomes.

The results of the descriptive analysis presented in Table 4 can reinforce the intended explanation. The mean value of science learning outcomes of experimental group students (taught with the PjBL strategy) with high self-regulation ability was 85.32, and the mean score of students in the experimental group with low self-regulation ability was 75.57 ; The mean score of control group students (taught with conventional strategies) with high $\mathrm{RD}$ ability was 71.91 , while the mean value of control group students with low RD ability was 70.30.

An interesting fact from this study results is that the average score of learning outcomes of students who have low selfregulation but learned using PjBL strategies is still higher than students who have high self-regulation but are taught using conventional strategies. This situation reinforces the notion that the PjBL strategy can increase student learning outcomes. Students with any self-regulation ability turned out to use the PjBL strategy to improve their learning outcomes. The condition is suspected because $\mathrm{PjBL}$ strategy has advantages in learning interactions between lecturers and students and between students and other students. For example, PjBL-based learning interactions always provide wider opportunities for students to explore their learning. Students are more flexible in finding and exploring information that can strengthen their mastery of various concepts they learn.

In contrast to students who are taught using conventional methods, students who have high self-regulation abilities, mean scores of learning outcomes are lower than students who have low self-regulation abilities who are taught with $\mathrm{PjBL}$ strategies. It is suspected that conventional learning does not provide opportunities for students to explore their abilities. Learners tend to be passive participants, waiting for instructions, and are always forced to accept learners' learning materials. Considering that students have often been dealing with similar learning strategies since elementary school, students tend to get bored with such monotonous learning.

The findings of research results related to the proof of the research hypothesis 1 show that there are differences in learning outcomes between students who were studied using the $\mathrm{PjBL}$ strategy with students who were taught using regular strategies. It can be interpreted that $\mathrm{PjBL}$ strategy has a plus value compared with the regular learning strategy. PjBL strategy's advantages can be learned from the concept and its application in building learning independence in the learners. Several factors are suspected to affect the improvement of student learning outcomes through project-based learning [13]. Woolfolk argues that learning is an active process of learning by not only accepting knowledge but actively choosing, practicing, caring, ignoring, reflecting, and making many other decisions to achieve its goals. According Reigeluth and CarrChellman [23], learning through experience is learning centered on learners, not placing learners as passive recipients, but as an active negotiator of their experience. In harmony with this thinking, PjBL strategy is expected to facilitate learners more actively, pay attention, choose, make decisions, reflect, and seek experience.

The research results related to research hypothesis 2 indicate that there are differences in learning outcomes between students who have high SRL ability with students who have low SRL capability. Students with high SRL capability can 
generally achieve better learning outcomes than students with low SRL capability. Students with high SRL skills tend to be more independent in learning. Students are no longer too dependent on other parties in learning and can determine for themselves about various things related to learning. Students with high SRL are thought to be better able to direct themselves to meaningful learning activities for themselves. They tend to be more able to determine what they need to do to achieve their learning goals. The condition is very different from the students whose low SRL ability is suspected of tending to do learning activities based on certain directions or directives. Students with high SRL capabilities are thought to have more positive thinking about their learning, so when they are exposed to a creative and challenging learning process they are more interested. Students with high SRL capability tend to feel more interested in learning using the PjBL method, making them more actively involved in the learning process. The situation is in line with the opinion of [13]" that learners who have high ability in managing their learning, can transform their mental abilities into academic skills and strategies". According to Zimmerman [7], students are said to have used self-regulation when the student has a strategy to activate metacognition, motivation, and behavior in their own learning process.

Findings of research results related to research hypothesis 3 indicate an interaction effect of PjBL strategy and SRL ability on student learning outcomes. The fact that is quite interesting from the results of this study is that the average score of student learning outcomes with low SRL but learning by PjBL strategy is still higher than students who have high SRL but learning by using conventional strategy. This situation reinforces the notion that the PjBL strategy can improve the achievement of student learning outcomes. Students with any level of SRL ability turn out the use of PjBL strategy can improve learning outcomes. The condition is suspected because the strategy of $\mathrm{PjBL}$ has advantages in the interaction of learning either between lecturers and students and between students and other students. For example, in PjBL-based learning, interaction always provides wider opportunities for students to explore their learning. Students more freely in searching and digging information that can strengthen his mastery of various concepts he learned.

Unlike conventional students, students with high selfregulation ability and mean scores of learning outcomes are lower than those who have low self-regulation ability studied with $\mathrm{PjBL}$ strategy. It is presumed that less conventional learning allows learners to explore their abilities. Learners tend to be passive participants, waiting for instructions, and constantly forced to accept the learner's subject matter. Given that students have often faced similar learning strategies from elementary school, they tend to be saturated with such monotonous learning.

Associated with SRL students' ability, it can be interpreted that PjBL will be more effective if taught to students who have high self-regulation skills, thus becoming a recommendation for learners to strengthen the ability of self-regulation in each learning. Thus, SRL can be said is a prerequisite for the effectiveness of the use of strategies PjBL and a perfect match in learning. Zimmerman mentions that "Self-regulation is important for learners because the main function in education is the continuous development of learning skills for the rest of his life" [7].

\section{Conclusions}

The research conclusions are: (1) There are differences in the results of science learning between students who are studied using PjBL strategies with students who are taught using regular learning strategies. (2) There is a difference in science learning results between students who have high SRL capability with low SRL capability. (3) There is an interaction of the PjBL strategy and the ability of SRL to the student learning outcomes.

\section{REFERENCES}

[1] C.M. Reigeluth, Instructional-design theories and models. Lawrence Erlbaum Associates, 1983

[2] B.J. Zimmerman, Attaining Self-Regulation. In Handbook of SelfRegulation (pp. 13-39). Elsevier, 2000.

[3] S. Zumbrunn, J. Tadlock A.D. Roberts, "Encouraging self-regulated learning in the classroom: A review of the literature," Metropolitan Educational Research Consortium (MERC), 2011.

[4] C.A. Wolters, "Regulation of motivation: Contextual and socia aspects," Teachers College Record, vol. 113, no. 2, pp. 265-283, 2011.

[5] K.R. Harris, B. Danoff Friedlander, B Saddler, R. Frizzelle and S Graham, "Self-Monitoring of Attention Versus Self-Monitoring of Academic Performance: Effects Among Students with ADHD in the General Education Classroom," The Journal of Special Education, vol. 39, no. 3, pp. 145-157, 2005.

[6] A.B.H. de Bruin, K.W. Thiede, G. Camp, and J. Redford, "Generating keywords improves metacomprehension and self-regulation in elementary and middle school children," Journal of Experimental Child Psychology, vol. 109, no. 3, pp. 294-310, 2011.

[7] B.J. Zimmerman, "Becoming a Self-Regulated Learner: An Overview," Theory Into Practice, vol. 41, no. 2, pp. 64-70, 2002

[8] A.K. Aiedah and K.C. Audrey Lee, "Application of Project-Based Learning in Students' Engagement in Malaysian Studies and English Language," Journal of Interdisciplinary Research in Education (JIRE), vol. 2, no. 1, pp. 37-46, 2012

[9] M. Bagheri, W.A. Wan Zah, M.C. Binti Abdullah and S.M. Daud, "Effects of Project-based Learning Strategy on Self-directed Learning Skills of Educational Technology Students," Contemporary Educational Technology, vol. 4, no. 1, pp. 15-29, 2013

[10] G. Bas, "Investigating the effects of project-based learning on students' academic achievement and attitudes towards english lesson," TOJNED : The Online Journal Of New Horizons In Education, vol. 1, no. 4, 2011.

[11] L. ChanLin, "Technology integration applied to project-based learning in science," Innovations in Education and Teaching International, vol. 45 , no. 1 , pp. $55-65,2008$

[12] L.A. Pervin and D. Cervone, Personality: Theory and research (11. ed., internat. student version). Wiley, 2010.

[13] A. Woolfolk, Educational psychology (3rd ed). Prentice-Hall, 1987.

[14] H.S. Friedman and M.W. Schustack, Personality: Classic theories and modern research (5th ed). Pearson Allyn \& Bacon, 2012. 
[15] P.R. Pintrich, "A Conceptual Framework for Assessing Motivation and Self-Regulated Learning in College Students," Educational Psychology Review, vol. 16, no. 4, pp. 385-407, 2004.

[16] D.H. Schunk, "Self-Regulated Learning: The Educational Legacy of Paul R. Pintrich,” Educational Psychologist, vol. 40, no. 2, pp. 85-94, 2005.

[17] S.G. Davis and E.S. Gray, "Going Beyond Test-Taking Strategies Building Self-Regulated Students and Teachers," Journal of Curriculum and Instruction, vol. 1, no. 1, pp. 42, 2007.

[18] D.H. Schunk, Motivation and self-regulated learning: Theory, research, and applications. Routledge, 2009.

[19] B.J. Zimmerman and D.H. Schunk, Self-regulated learning and academic achievement: Theoretical perspectives (2nd ed). Lawrence Erlbaum Associates Publishers, 2001.
[20] L. Jong Ki, "The Effects of Self-Regulated Learning Strategies and System Satisfaction Regarding Learner's Performance in E-Learning Environment," Journal of Instructional Pedagogies, 1, 2009.

[21] P.C. Blumenfeld, E. Soloway, R.W. Marx, J.S. Krajcik, M. Guzdial, M., and A. Palincsar, "Motivating Project-Based Learning: Sustaining the Doing, Supporting the Learning," Educational Psychologist, vol. 26, no. 3-4, pp. 369-398, 1991.

[22] M.D. Gall, J.P. Gall and W.R. Borg, Educational research: An introduction (8th ed). Pearson/Allyn \& Bacon, 2007.

[23] C.M. Reigeluth and A.A. Carr-Chellman, Instructional-design theories and models. Volume III, Volume III, https://0-www. taylorfrancis. com. cataleg. uoc.edu/books/e/9781135211073, 2009. 